\title{
Leptin Regulates Tau Phosphorylation through Wnt Signaling Pathway in PC12 Cells
}

\author{
Zijuan Zhanga,b Meixia Guoc Juan Zhang ${ }^{a}$ Caixia Du ${ }^{a} \quad$ Ying Xing ${ }^{b}$ \\ aExperimental teaching center, Basic Medical College of Henan University of Chinese Medicine, \\ Zhengzhou, 'Department of Physiology, University of Zhengzhou, 'Department of Physiology, SanQuan \\ Medical College, XinXiang Medical University, Xinxiang, China
}

\section{Key Words}

Alzheimer's disease $\bullet$ PC12 cells $\bullet$ Wnt • Tau • Leptin

\begin{abstract}
Background/Aims: Leptin, an adipocytokine produced endogenously in the brain, is decreased in Alzheimer's disease(AD) and has also been shown to reduce $A \beta$ levels in vitro and in vivo. Sets of evidence show that leptin reduces $A \beta$ production and tau phosphorylation in neuronal cells and transgenic mice models of AD. Herein, we investigated the signaling pathway activated by leptin, to better understand its mechanism of action. Methods: Western blotting was performed to assess the levels of phosphor-tau and Bax, RT-PCR to check the mRNA level of Bax. Results: Leptin treatment significantly blunted $A \beta$-evoked tau phosphorylation and Bax levels, effects of which could be reversed by antagonist of Wnt signaling. Conclusion: The data indicate that Leptin may provide a novel therapeutic approach to $A D$ treatment via wnt signaling.

\section{Introduction}

The most common neurodegenerative dementia is Alzheimer's disease (AD), which is characterized by two major pathological hallmarks: the deposition and accumulation of $\beta$-amyloid $(A \beta)$ peptide in extracellular plaques, the deposition of hyper-phosphorylated tau in intracellular neurofibrillary tangles (NFTs) [1]. Compared to A $\beta$ plaques, NFT with the brain correlates better with neurodegeneration and cognitive decline [2].

Leptin is a 16-kDa peptide hormone and inflammatory cytokine involved in regulating food intake, metabolism, body fat, energy expenditure and neuroendocrine function [3]. Moreover, 
Zhang et al.: Wnt Regulates Tau Phosphorylation

a decline of leptin levels is common in $\mathrm{AD}$ [4]. Additionally, leptin reduces $\mathrm{A} \beta$ levels in vitro and in vivo [5-7]. Sets of evidence show that leptin reduces $A \beta$ production and tau phosphorylation in neuronal cells and transgenic mice models of $\mathrm{AD}[8,9]$. Fewlass et al. has found the leptin's ability to modify $A \beta$ levels in vitro and in vivo [10]. Interestingly, leptin suppresses $A \beta$ degradation in astrocytes and increases apoE-dependent $A \beta$ uptake in vitro [10]. Indeed, leptin signaling is involved in ApoE gene expression and would exert this effect on the removal of $A \beta$ aggregates [11]. Therefore, leptin modulates bidirectional $A \beta$ kinesis reducing its extracellular levels [12].

Moreover, leptin up-regulates Wnt in breast cancer cells [13]. Wnt/ $\beta$-catenin signaling pathway is involved not only in the formation of the embryonic dorsoventral axis, but also in a number of other developmental events that depend on establishment of cell polarity or determination of cell fate [14]. Glycogen synthase kinase 3(GSK3), a key component of the $\beta$-catenin destruction complex, phosphorylates $\beta$-catenin at Ser33, Ser37, and Thr41, leading to its degradation by the proteasome $[15,16]$. Of note, GSK-3 is highly expressed in the brain of AD patients [17], which results in the over-phosphorylation of Tau and the formation of NTF [18].

We have previously described that Wnt/ $\beta$-catenin signaling pathway is involved in the neurotoxic effects of $A \beta_{25-35}$ [19]. Herein, we investigated whether leptin regulated tau phosphorylation via Wnt signaling pathway in $\mathrm{A} \beta_{25-35}$-pretreated PC12 cells.

\section{Materials and Methods}

\section{Cell culture}

Highly differentiated neuron-like PC12 cells(Shanghai Institutes for Biological Sciences, the Chinese Academy of Sciences, Shanghai, China) were cultured in DMEM medium supplemented with 10\% FCS and 1\% penicillin/streptomycin under standard conditions.

It is reported that addition of purified $A \beta$ and of its active fragment $A \beta_{25-35}$ can induce apoptosis in a variety of mammalian cell type in vitro [20]. Therefor, Cells grown on the coverslips were pretreated in $30 \mu \mathrm{M}$ $\mathrm{A} \beta_{25-35}$ (Sigma Aldrich,USA) in the presence or absence of leptin(Sigma Aldrich,USA) and/or Wnt antagonist DKK1(Sigma Aldrich,USA) for 24h.

\section{Western blotting}

To examine the protein abundance, cells were lysed in RIPA buffer (Beyotime, Shanghai, China) containing $1 \%$ phenylmethylsulfonyl fluoride (Beyotime) and 1\% protein phosphatase inhibitor (Beyotime) on ice for $30 \mathrm{~min}$. The samples were centrifuged at $14,000 \mathrm{rpm}$ and $4^{\circ} \mathrm{C}$ for $20 \mathrm{~min}$. Loading buffer (Beyotime, Shanghai, China) was added to the protein lysate, which then were incubated at $95^{\circ} \mathrm{C}$ for $5 \mathrm{~min}$.

Total proteins (40-60 $\mu \mathrm{g}$ ) were separated by electroporation on 10\% SDS-PAGE. For immunoblotting proteins were electro-transferred onto PVDF membranes and blocked with 5\% nonfat milk in triethanolaminebuffered saline (TBS) with $0.1 \%$ Tween 20 (TBS-T) at room temperature for $1 \mathrm{~h}$. Then, the membrane was incubated with polyclonal rabbit anti-p-tauSer235(1:1000, cell signaling), Bax(1:1000, cell signaling) at $4^{\circ} \mathrm{C}$ overnight. All antibodies were diluted in TBS-T with 5\% BSA. After washing with TBST the blots were incubated with secondary anti rabbit secondary antibody (1:2000, Sigma, United States) for $1 \mathrm{~h}$ at room temperature. After washing antibody binding was visualized with enhanced chemiluminescence reagents(Beyotime, Shanghai, China). Membranes were also probed with Actin antibody as loading control. Densitometric analysis was performed using quantity One software (Abbiotec, United States).

\section{Quantification of mRNA expression}

Total RNA was extracted from PC12 cells in TriFast (Peqlab, United States) according to the manufacturer's instructions. After DNAse digestion reverse transcription of total RNA was performed using Transcriptor High Fidelity cDNA Synthesis Kit (Roche Diagnostics, United States). Real-time polymerase chain reaction (RT-PCR) of the respective genes were set up in a total volume of $20 \mu \mathrm{l}$ using $40 \mathrm{ng}$ of cDNA, $500 \mathrm{nM}$ forward and reverse primer and 2x GoTaq ${ }^{\circledR}$ qPCR Master Mix (Promega, United States) according to the manufacturer's protocol. Cycling conditions were as follows: initial denaturation at $95^{\circ} \mathrm{C}$ for $2 \mathrm{~min}$, followed by 40 cycles of $95^{\circ} \mathrm{C}$ for 15 $\mathrm{sec}, 58^{\circ} \mathrm{C}$ for $15 \mathrm{sec}$ and $68^{\circ} \mathrm{C}$ for $20 \mathrm{sec}$. For amplification the following primers were used ( $5^{`}>3^{`}$ orientation): 
The following primers were used:

Human Tbp (TATA box-binding protein):

forward (5'-3'): ACTCCTGCCACACCAGCC

reverse (5'-3'): GGTCAAGTTTACAGCCAAGATTCA

Human Bax

forward (5'-3'): ATGTGAAGCACCCTTTCCTG

reverse (5'-3'): TAGAACAGCTCTCCGCCATT

Specificity of PCR products was confirmed by analysis of a melting curve. Real-time PCR amplifications were performed on a CFX96 Real-Time System (Bio-Rad, Munich, Germany) and all experiments were done in duplicate. The house-keeping gene Tbp (TATA binding protein) was amplified to standardize the amount of sample RNA. Relative quantification of gene expression was achieved using the $\Delta$ CT method as described [21].

\section{Statistics}

Data are provided as means \pm SEM, $n$ represents the number of independent experiments. All data were tested for significance using unpaired Student t-test or ANOVA followed by post hoc Bonferroni test was applied when multiple comparisons between different groups were made. Only results with $\mathrm{p}<0.05$ were considered statistically significant.

\section{Results}

In order to explore whether the effect of leptin on $\mathrm{A} \beta_{25-35}$-mediated tau phosphorylation is Wnt-dependent, $A \beta_{25-35}$-pretreated PC12 cells were treated with leptin $(125 \mathrm{ng} / \mathrm{ml})$ in the presence or absence of DKK1 $(100 \mathrm{ng} / \mathrm{ml})$. As illustrated in Fig. 1, leptin significantly alleviated Leptin-mediated inhibition of $A \beta_{25-35}$ phosphorylation of Tau at Ser235.

The BAX gene was the first identified pro-apoptotic member of the Bcl-2 protein family. Western Blot was utilized to quantity the expression of Bax protein in PC12 cells. As shown in Fig. 2, the expression level of Bax protein in control group was less than that in $A \beta_{25-35}$ group, and leptin blocked $A \beta_{25-35}$-induced increase of Bax expression. In addition, DKK1(100 ng/ml)

Fig. 1. Leptin abolished $A \beta_{25-35}$-induced tau phosphorylation by Wnt signaling in PC12 cells. (A) Original western blot showing the levels of phosphor-tau and total tau protein as well as respective actin in $\mathrm{A} \beta_{25-35}$-pretreated PC12 cells without or with Leptin $(125 \mathrm{ng} / \mathrm{ml})$ in the presence or absence of DKK1 $(100 \mathrm{ng} / \mathrm{ml})$. (B) Arithmetic means \pm SEM ( $\mathrm{n}=3$ independent experiments) of p-tau in in $A \beta_{25-35}$-pretreated PC12 cells without or with Leptin(125 ng/ $\mathrm{ml}$ ) in the presence or absence of DKK1 (100 ng/ml). ${ }^{* *}(\mathrm{p}<0.01),{ }^{* * *}(\mathrm{p}<0.001)$ indicate statistically significant difference.

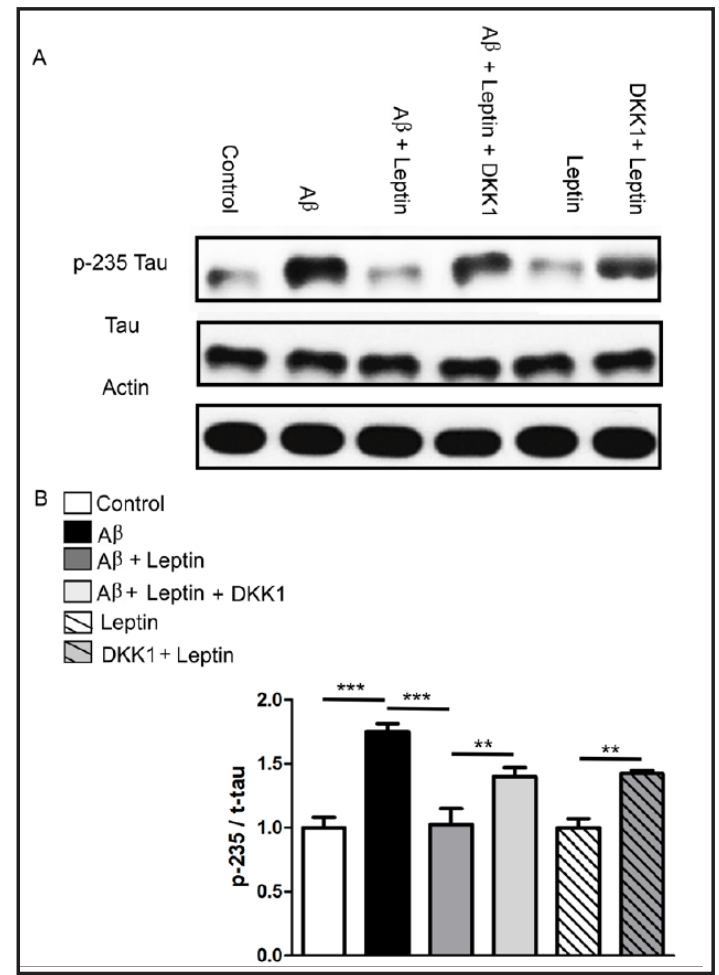


Fig. 2. Leptin regulated $A \beta_{25-35}$-evoked Bax expression via Wnt in PC12 cells. (A) Original western blot showing the protein abundance of Bax as well as respective actin in $\mathrm{A} \beta_{25-35}$-pretreated PC12 cells without or with Leptin $(125 \mathrm{ng} / \mathrm{ml})$ in the presence or absence of DKK1 (100 ng/ml). (B) Arithmetic means \pm SEM ( $n=4$ independent experiments) of bax in $\mathrm{A} \beta_{25-35}$-pretreated PC12 cells without or with Leptin in the presence or absence of DKK1 (100 ng/ $\mathrm{ml}) .{ }^{* *}(\mathrm{p}<0.01),{ }^{* * *}(\mathrm{p}<0.001)$ indicate statistically significant difference.

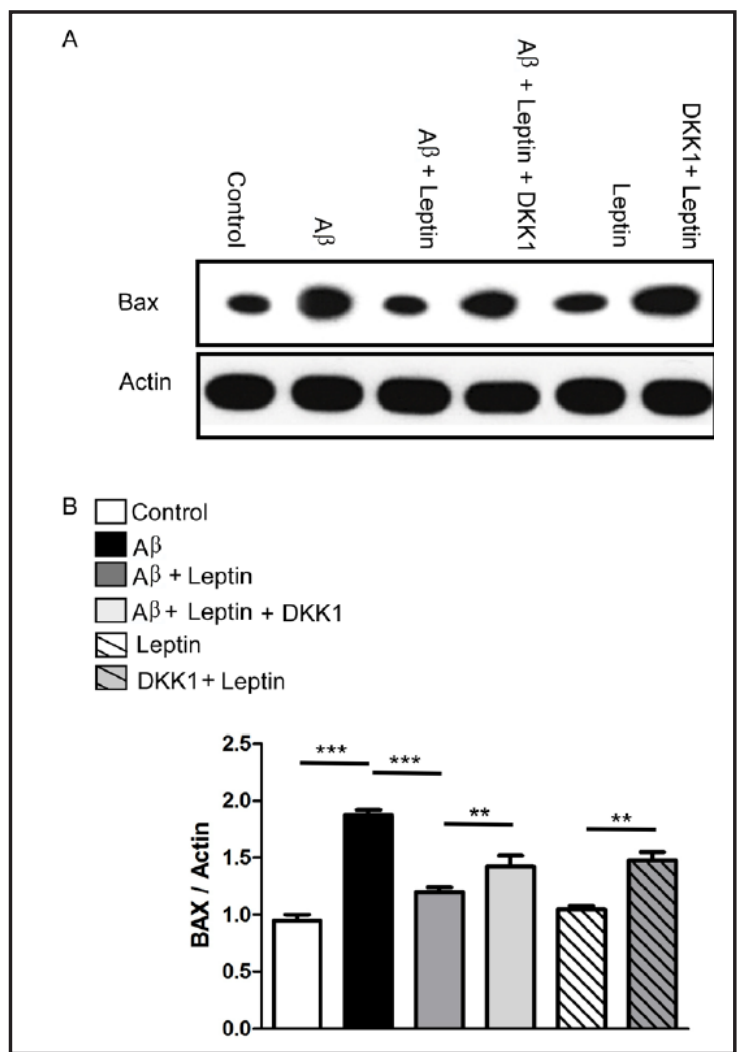

Fig. 3. Leptin effected $A \beta_{25-35}$-evoked Bax transcriptional expression through Wnt in PC12 cells. Arithmetic means \pm SEM $(n=4$ independent experiments) of Bax mRNA level in $\mathrm{A} \beta_{25-35}$-pretreated PC12 cells without or with Leptin in the presence or absence of DKK1 $(100 \mathrm{ng} / \mathrm{ml}) .{ }^{* *}(\mathrm{p}<0.01)$, $* * *(\mathrm{p}<0.001)$ indicate statistically significant difference.

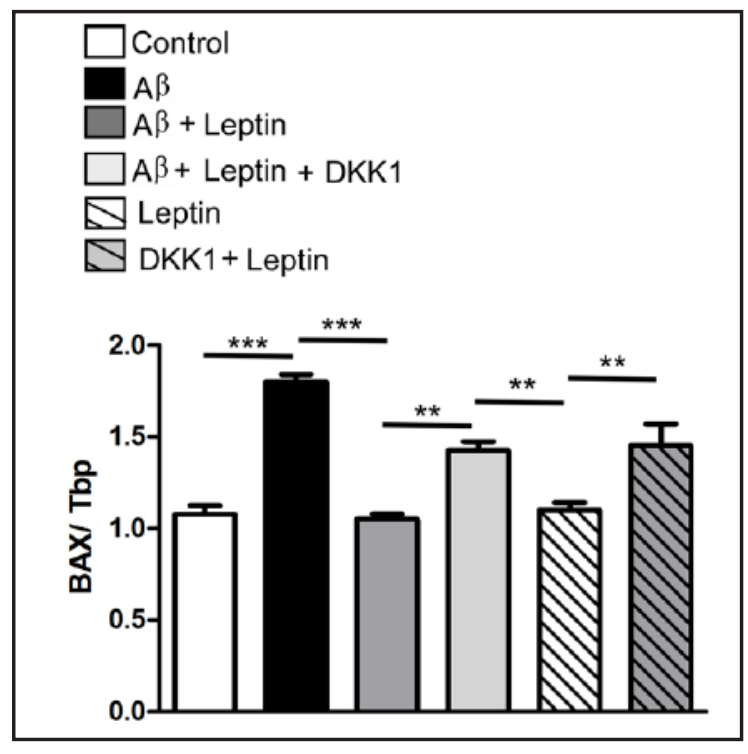

significantly blunted Leptin-regulated inhibition of $\mathrm{A} \beta_{25-35}$ upon the protein abundance of Bax.

In order to confirm whether Wnt/ $\beta$-catenin signaling pathway associates with the mRNA levels of Bax, qRT-PCR was utilized. As illustrated in Fig. 3, leptin(125 ng/ml) alleviated $\mathrm{A} \beta_{25-35}$-mediated increase of Bax, the effect of which was affected by DKK1.

GSK3 is a key component of the $\beta$-catenin destruction complex. To further understand the role of leptin, $A \beta_{25-35}$-pretreated PC12 cells were treated with leptin in the absence and presence of DKK1, then Western blot was applied. As illustrated in Fig. 4, treatment with DKK1(100 ng/ml) blunted Leptin-mediated inhibition of GSK3 protein abundance. 
Fig. 4. GSK-3 protein abundance in $A \beta_{25-35}$-pretreated PC12 cells. (A) Original western blot showing the protein abundance of GSK-3 and respective actin in untreated and Leptin treatment $(125 \mathrm{ng} / \mathrm{ml})$ PC12 cells in the presence of DKK1 $(100 \mathrm{ng} / \mathrm{ml})$ in $\mathrm{A} \beta_{25-35}$-pretreated PC12 cells. (B) Arithmetic means \pm SEM ( $\mathrm{n}=4$ independent experiments) of GSK- 3 and respective actin protein abundance without(white bar) and with Leptin treatment $(125 \mathrm{ng} / \mathrm{ml})($ dark bar) in the presence of DKK1 (100 ng/ml)(grey bar) in in $\mathrm{A} \beta_{25-35}$-pretreated PC12 cells. ${ }^{* * *}(\mathrm{p}<0.001)$ indicate statistically significant difference.

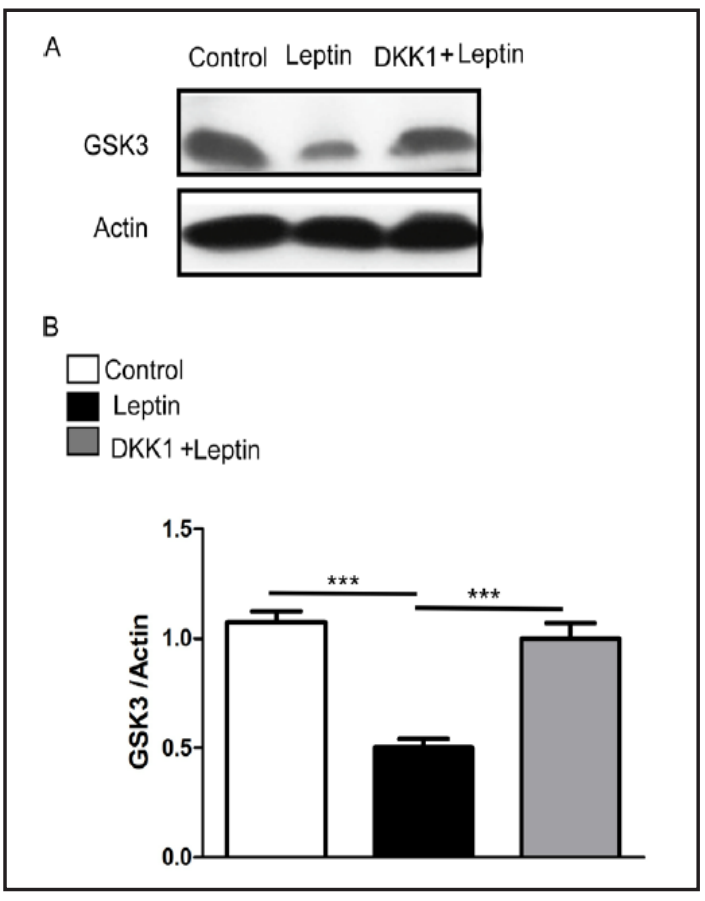

\section{Discussion}

This study was conceived to assess the role of leptin signaling in the modulation of AD and explore the related mechanism. Leptin is known to activate Wnt in cancer cells [22], and we have previously demonstrated that Wnt/ $\beta$-catenin signaling pathway blunted $A \beta_{25-35}$-mediated inhibition upon Bcl-2/Bax ratio in PC12 cells by affecting GSK3 $[19,23]$. Our present findings indicate that Wnt mediates leptin's effect upon tau phosphorylation and apoptosis.

Leptin, the level of which is significantly decreased in $\mathrm{AD}$ patients, improves cognitive disorders and referred to as a potential cognitive enhancer [24]. Reports have shown that Leptin reduces $A \beta$ levels both in vitro and in vivo, and inhibits tau phosphorylation in neuronal cultures [7]. Moreover, leptin is known to activate Wnt via Jak2 signaling pathway in cancer cells [22], but it is still elusive as to how leptin modulates Wnt signaling in neuronal cells. Sets of evidence point to a possible role for Wnt in AD[25-27]. Precisely, De Ferrari et al. found that $A \beta$-dependent neurotoxicity induced a loss of function of Wnt signaling components [25].We showed that leptin abrogated A $\beta$-induced tau phosphorylation and apoptosis-related protein, an effect of which is Wnt dependent.

GSK3 $\beta$, a downstream effector of Wnt signaling pathway, is highly expressed in the brain of AD patients [17] and results in the over-phosphorylation of Tau and the formation of NTF [18]. It is known that A $\beta$ promotes GSK3 activation [28]. We found that inhibition of Wnt reversed leptin-reduced GSK-3 $\beta$ expression in PC12 cells. These findings suggest that Leptin, and potentially Wnt activators, may provide a novel therapeutic approach to AD treatment.

\section{Disclosure Statement}

The authors state that they have no conflict of interest.

\section{References}

1 Chiba T, Yamada M, Sasabe J, Terashita K, Shimoda M, Matsuoka M, Aiso S: Amyloid-beta causes memory impairment by disturbing the JAK2/STAT3 axis in hippocampal neurons. Mol Psychiatry 2009;14:206-222. 
Zhang et al.: Wnt Regulates Tau Phosphorylation

2 Guillozet AL, Weintraub S, Mash DC, Mesulam MM: Neurofibrillary tangles, amyloid, and memory in aging and mild cognitive impairment. Arch Neurol 2003;60:729-736.

3 Gonzalez RR, Cherfils S, Escobar M, Yoo JH, Carino C, Styer AK, Sullivan BT, Sakamoto H, Olawaiye A, Serikawa T, Lynch MP, Rueda BR: Leptin signaling promotes the growth of mammary tumors and increases the expression of vascular endothelial growth factor (VEGF) and its receptor type two (VEGF-R2). J Biol Chem 2006;281:26320-26328.

4 Gustafson D: Adiposity indices and dementia. Lancet Neurol 2006;5:713-720.

5 Tezapsidis N, Johnston JM, Smith MA, Ashford JW, Casadesus G, Robakis NK, Wolozin B, Perry G, Zhu $\mathrm{X}$, Greco SJ, Sarkar S: Leptin: a novel therapeutic strategy for Alzheimer's disease. J Alzheimers Dis 2009;16:731-740.

6 Ishii M: The Role of the Adipocyte Hormone Leptin in Alzheimer's Disease. Keio J Med 2016;65:21-21.

7 Magalhães CA, Carvalho MG, Sousa LP, Caramelli P, Gomes KB: Leptin in Alzheimer's disease. Clin Chim Acta 2015;450:162-168.

8 Li X-M, Yan H-J, Guo Y-S, Wang D: The role of leptin in central nervous system diseases. Neuroreport 2016;27:350-355.

9 Wu K, Tan X-Y, Xu Y-H, Chen Q-L, Pan Y-X: JAK and STAT members of yellow catfish Pelteobagrus fulvidraco and their roles in leptin affecting lipid metabolism. Gen Comp Endocrinol 2016;226:14-26.

10 Fewlass DC, Noboa K, Pi-Sunyer FX, Johnston JM, Yan SD, Tezapsidis N: Obesity-related leptin regulates Alzheimer's Abeta. FASEB J $2004 ; 18: 1870-1878$.

11 Folch J, Pedrós I, Patraca I, Sureda F, Junyent F, Beas-Zarate C, Verdaguer E, Pallàs M, Auladell C, Camins A: Neuroprotective and anti-ageing role of leptin. J Mol Endocrinol 2012;49:R149-56.

12 Greco SJ, Bryan KJ, Sarkar S, Zhu X, Smith MA, Ashford JW, Johnston JM, Tezapsidis N, Casadesus G: Leptin reduces pathology and improves memory in a transgenic mouse model of Alzheimer's disease. J Alzheimers Dis 2010;19:1155-1167.

13 Dirat B, Bochet L, Dabek M, Daviaud D, Dauvillier S, Majed B, Wang YY, Meulle A, Salles B, Le Gonidec S, Garrido I, Escourrou G, Valet P, Muller C: Cancer-associated adipocytes exhibit an activated phenotype and contribute to breast cancer invasion. Cancer Res 2011;71:2455-2465.

14 Li X, Guan Y, Chen Y, Zhang C, Shi C, Zhou F, Yu L, Juan J, Wang X: Expression of Wnt5a and its receptor Fzd2 is changed in the spinal cord of adult amyotrophic lateral sclerosis transgenic mice. Int J Clin Exp Pathol 2013;6:1245-1260.

15 Zeng X, Tamai K, Doble B, Li S, Huang H, Habas R, Okamura H, Woodgett J, He X: A dual-kinase mechanism for Wnt co-receptor phosphorylation and activation. Nature 2005;438:873-877.

16 Patel S, Doble B, Woodgett JR: Glycogen synthase kinase-3 in insulin and Wnt signalling: a double-edged sword? Biochem Soc Trans 2004;32:803-808.

17 Asuni AA, Hooper C, Reynolds CH, Lovestone S, Anderton BH, Killick R: GSK3alpha exhibits beta-catenin and tau directed kinase activities that are modulated by Wnt. Eur J Neurosci 2006;24:3387-3392.

18 Caccamo A, Maldonado MA, Majumder S, Medina DX, Holbein W, Magrí A, Oddo S: Naturally secreted amyloid-beta increases mammalian target of rapamycin (mTOR) activity via a PRAS40-mediated mechanism. J Biol Chem 2011;286:8924-8932.

19 Wang J, Jing Y, Song L, Xing Y: Neuroprotective Effects of Wnt / ß-catenin signaling pathway against A $\beta$ -induced Tau protein over-phosphorylation in PC12 cells. Biochem Biophys Res Commun 2016; DOI: 10.1016/j.bbrc.2016.01.130

20 Blasko I, Wagner M, Whitaker N, Grubeck-Loebenstein B, Jansen-Dürr P: The amyloid beta peptide abeta (25-35) induces apoptosis independent of p53. FEBS Lett 2000;470:221-225.

21 Matsuzaki T, Iwasa T, Tungalagsuvd A, Munkhzaya M, Kawami T, Yamasaki M, Murakami M, Kato T, Kuwahara A, Yasui T, Irahara M: The responses of hypothalamic NPY and OBRb mRNA expression to food deprivation develop during the neonatal-prepubertal period and exhibit gender differences in rats. Int J Dev Neurosci 2015;41:63-67.

22 Wolfson B, Eades G, Zhou Q: Adipocyte activation of cancer stem cell signaling in breast cancer. World J Biol Chem 2015;6:39-47.

23 Zheng Y, Wang J, Li D, Guo M, Zhen M, Chang Q: Wnt / ß-Catenin Signaling Pathway Against A $\beta$ Toxicity in PC12 Cells. Neurosignals 2016;24:40-47. 
Zhang et al.: Wnt Regulates Tau Phosphorylation

24 Zhang H, He Y-F, Li A-P: [The Role of Leptin in Cognitive Development During Aging]. Sheng Li Ke Xue Jin Zhan 2015;46:321-326.

25 De Ferrari GV, Chacón MA, Barría MI, Garrido JL, Godoy JA, Olivares G, Reyes AE, Alvarez A, Bronfman M, Inestrosa NC: Activation of Wnt signaling rescues neurodegeneration and behavioral impairments induced by beta-amyloid fibrils. Mol Psychiatry 2003;8:195-208.

26 Gopalakrishnan N, Saravanakumar M, Madankumar P, Thiyagu M, Devaraj H: Colocalization of $\beta$-catenin with Notch intracellular domain in colon cancer: a possible role of Notch1 signaling in activation of CyclinD1-mediated cell proliferation. Mol Cell Biochem 2014;396:281-293.

27 Woo H-N, Park J-S, Gwon A-R, Arumugam TV, Jo D-G: Alzheimer's disease and Notch signaling. Biochem Biophys Res Commun 2009;390:1093-1097.

28 Hernández F, Gómez de Barreda E, Fuster-Matanzo A, Lucas JJ, Avila J: GSK3: a possible link between beta amyloid peptide and tau protein. Exp Neurol 2010;223:322-325. 